\title{
Immune biomarkers in irritable bowel syndrome: a review
}

This article was published in the following Dove Press journal:

Current Biomarker Findings

16 June 2013

Number of times this article has been viewed

\section{Beatriz Gras-Miralles Efi Kokkotou}

Gastroenterology Department, Beth Israel Deaconess Medical Center, Harvard Medical School, Boston, MA, USA
Correspondence: Efi Kokkotou Beth Israel Deaconess Medical Center, Division of Gastroenterology, 330 Brookline Avenue, DA-50I, 02215, Boston, MA, USA

Tel + I 6176670549

Fax + I 6176672767

Email ekokkoto@bidmc.harvard.edu
Abstract: Irritable bowel syndrome (IBS) is a chronic functional gastrointestinal disorder that affects about $9 \%-13 \%$ of the general population. IBS is one of the main reasons to consult a primary care physician, and nearly $30 \%$ of visits to a gastroenterologist are for IBS. The diagnosis of IBS relies on subjective, patient-reported symptoms, thus making urgent the need for IBS-specific biomarkers. The same biomarkers, or perhaps different ones, can also be used to monitor disease evolution and response to treatment. A significant number of studies have looked in the immune system for establishing IBS biomarkers, based on the concept that IBS might represent a condition of immune dysregulation somewhere in the spectrum between health and inflammatory bowel disease. Such biomarkers can be detected in blood, intestinal biopsies, or luminal contents. Overall, results are rarely consistent between studies; small sample size, patient and disease heterogeneity, presence of comorbidities, and variation in sampling might contribute to these discrepancies. So far, studies have failed to provide a diagnostic immune biomarker for IBS, but they have considerably advanced our understanding of the disease pathophysiology, including the role of the individual's genetic make-up, and of the host-microbial interactions. High throughput analysis of a large number of well characterized patients holds promise for developing appropriate biomarkers for IBS.

Keywords: neuroimmune interactions, mast cells, genetic polymorphisms, cytokines, toll-like receptors

\section{Introduction}

Irritable bowel syndrome (IBS) is a chronic functional gastrointestinal disorder characterized by recurrent abdominal pain or discomfort and change in bowel habits. ${ }^{1,2}$ IBS is clinically classified into different subgroups: IBS with constipation predominance (IBS-C), IBS with diarrhea predominance (IBS-D), mixed or alternating IBS (IBS-M), and unsubtyped IBS (IBS-U). ${ }^{1}$

Post-infectious IBS (PI-IBS) is one special subgroup that meets the Rome criteria for IBS-D or IBS-M. In 6\%-7\% cases, IBS develops following an episode of viral or bacterial gastroenteritis. ${ }^{3-5}$ More toxigenic organisms increase the risk elevenfold, as does an initial illness lasting more than 3 weeks. Other risk factors for developing PI-IBS include severity of the initial insult, female sex, anxiety, and depression. ${ }^{6,7}$ In general, PI-IBS has a better prognosis, with a decrease or resolution of the symptoms within 10 years after the diagnosis. ${ }^{8}$

According to a recent meta-analysis of 80 studies including a total of 260,960 patients, the prevalence of IBS is estimated at $11.2 \%(95 \%$ confidence interval $[\mathrm{CI}]$, $9.8 \%-12.8 \%$ ). Females are at slightly higher risk for IBS compared with males (OR, 1.67; 
95\% CI, 1.53-1.82). ${ }^{9}$ IBS is one of the top reasons to consult a physician: it accounts for $10 \%-15 \%$ of primary care visits and $25 \%-50 \%$ of gastroenterology referral visits. ${ }^{10,11}$ In the United States alone, US\$1.7-10 billion in direct medical costs per year (ie, primary and specialist physician visits, diagnostic tests, etc) have been associated with IBS, excluding prescription and over-the-counter drug costs; ${ }^{12,13}$ and up to US\$20 billion in indirect costs (eg, productivity loss). ${ }^{14}$ Further, the disease has a negative impact on health-related quality of life parameters both in IBS patients and their family members. ${ }^{15}$

Diagnosis of IBS as defined by the Rome III criteria is based on patient reported symptoms, which are mainly subjective and prone to recall bias. ${ }^{1,2,16}$ Often, the lack of findings by endoscopy or laboratory tests in these patients has led to the concept of "diagnosis by exclusion". Furthermore, it drives high expenses in the diagnostic process to exclude other organic conditions that can present with similar symptoms, including gastrointestinal infections or inflammatory bowel disease (IBD). Therefore, the development of objective criteria for disease diagnosis and/or monitoring response to treatment in IBS remains an unmet need.

A disease biological marker, or biomarker, is defined as a change in the physical composition of an organism that can be objectively measured. It indicates the presence of an illness, can reflect the activity of the disease, or may be used to evaluate the pharmacological response to a therapeutic intervention. ${ }^{17,18}$ Biomarkers can be developed based on known biological pathways implicated in disease pathogenesis, or from unbiased high-throughput screening of well defined clinical populations. ${ }^{19}$ In that case, the identified biomarkers can also provide insight into potential disease mechanisms.

\section{Cellular biomarkers in IBS}

The prevailing notion is that IBS represents a state of chronic low-grade inflammation of the intestinal mucosa, being somewhere in the spectrum between healthy mucosa and IBD. ${ }^{20,21}$ While some studies demonstrate increased numbers of immune cells, particularly T-lymphocytes, in the colonic mucosa of patients with IBS, consensus is lacking, since a significant number of other reports fail to show any differences compared with healthy controls (Table 1). Cremon et $\mathrm{al}^{22}$ studied 48 patients with IBS and 24 healthy controls (HC) and found a greater number of immune cells infiltrating the colonic mucosa in patients with IBS. These cells appear to be primarily T-lymphocytes $\left(\mathrm{CD}^{+}, \mathrm{CD}^{+}, \mathrm{CD}^{+}\right) .{ }^{22}$ Similar findings are presented by Piche et $\mathrm{al},{ }^{23}$ who studied 50 patients with IBS and $21 \mathrm{HCs}$. Furthermore, Chadwick et $\mathrm{al}^{24}$ reported an increase in $\mathrm{CD}^{+} \mathrm{CD} 25^{+}$activated T-cells in 38 patients with IBS, despite the lack of histologically confirmed active inflammation. Similarly, Ohman et al ${ }^{25,26}$ described an increase in circulating $\mathrm{CD}^{+}$and $\mathrm{CD} 8^{+} \mathrm{T}$-cells expressing activation markers such as $\mathrm{CD} 69^{+}$and $\beta 7^{+} \mathrm{HLADR}^{+}$, but not $\mathrm{CD} 25^{+}$. However, Holmen et $\mathrm{al}^{27}$ did not find any changes in the number of $\mathrm{CD} 4{ }^{+} \mathrm{CD} 25^{+}$cells, either in the colonic mucosa or blood of 34 patients with IBS. Moreover, mRNA colonic expression of FoxP3, a marker for regulatory T-cells was comparable between IBS patients and controls. ${ }^{28}$ The group from Nottingham led by Spiller focused on patients with PI-IBS and found a significant increase of $\mathrm{CD}^{+}$cells, as well as $\mathrm{CD}^{+}$cells in the rectal mucosa of patients with PI-IBS. ${ }^{29,30} \mathrm{Akbar}$ et $\mathrm{al}^{31}$ reported analogous results in a study of 23 patients with IBS.

Among the studies with negative results, Kindt et $\mathrm{al}^{32}$ and Ohman et $\mathrm{al}^{25}$ found comparable numbers of total lymphocytes, $\mathrm{CD}^{+}$cells, and $\mathrm{CD} 8^{+}$cells in the blood of patients with IBS and controls. Likewise, Chang et $\mathrm{al}^{33}$ reported no differences in the number of $\mathrm{CD}^{+}$cells, $\mathrm{CD}^{+}$cells, or $\mathrm{CD}^{+}$cells when they examined biopsies from sigma of 45 patients with IBS. Similar findings are reported by Park et al, ${ }^{34} \mathrm{O}$ 'Sullivan et al, ${ }^{35}$ and Lee et al. ${ }^{36}$ Interestingly, Braak et $\mathrm{al}^{28}$ described a lower number of $\mathrm{CD}^{+}$cells in the colon of 66 patients with IBS, while the total number of $\mathrm{CD}^{+}$ cells remained unaltered.

Fewer studies have examined the role of B-cells in IBS. Forshammar et $\mathrm{al}^{37}$ found deceased $\operatorname{IgA}^{+}$cells in the colon of 12 patients with IBS, while Ohman et $\mathrm{al}^{38}$ reported a significant increase in $\mathrm{IgG}^{+}$cells in the blood of 74 patients with IBS, as well as in activated B-cells (CD80+ or CD86 $\left.{ }^{+}\right)$. However, Cremon et $\mathrm{al}^{22}$ found no differences in $\mathrm{CD}^{2} 9^{+}$ B-cells in the colonic mucosa of 48 patients with IBS, and Kindt et $\mathrm{al}^{32}$ in the number of B-cells in the blood of 30 patients with IBS. Consistent with the above were the studies of Park et $\mathrm{al}^{34}$ and O'Sullivan et al. ${ }^{35}$

The number of eosinophils in the colonic mucosa of patients with IBS was found consistently to be similar to that of controls in four studies, ${ }^{23,34,35,39}$ while neutrophils are reported unaltered, ${ }^{23,34,39}$ increased $^{24}$ or decreased ${ }^{35}$ in different studies. Notably, two studies report a decrease in $\mathrm{CD}^{2} 8^{+}$-macrophages in the colonic mucosa of 66 patients with IBS $^{28}$ and in the rectal mucosa of 16 patients with PI-IBS. ${ }^{30}$

Mast cells are also an important component of the immune system. In the intestinal mucosa, they are mainly found surrounding vessels and nerves. When activated, they release a number of biologically active substances primarily histamine, serotonin, and diverse proteases. They can also release cytokines and several arachidonic acid metabolites including prostaglandins and leukotriens. ${ }^{40}$ 
Table I Immune activation in IBS

\begin{tabular}{|c|c|c|c|c|c|c|c|}
\hline Study & $\mathbf{N}^{\mathbf{a}}$ & Anatomic location & $\mathrm{T}-\mathrm{CD} 3^{+\mathrm{b}, \mathrm{c}}$ & T-CD4 $4^{+b, c}$ & $\mathrm{~T}-\mathrm{CDB}^{+\mathrm{b}, \mathrm{c}}$ & B-cells ${ }^{b, c}$ & Other ${ }^{b, c}$ \\
\hline \multirow[t]{2}{*}{ Foley et $\mathrm{al}^{45}$} & 20 IBS-D"II & Duodenum & & & & & $\uparrow * *$ intraepithelial \\
\hline & $29 \mathrm{HC}$ & & & & & & lymphocytes \\
\hline Guilarte & 20 IBS-D" & Jejunum & $\uparrow$ 料 & & & & \\
\hline et $\mathrm{al}^{46}$ & $14 \mathrm{HC}$ & & & & & & \\
\hline \multirow[t]{4}{*}{ Park et $\mathrm{al}^{34}$} & I8 IBS-D" & Ileum & & & & & $\leftrightarrow$ lympohcytes \\
\hline & $15 \mathrm{HC}$ & Colon & & & & & $\leftrightarrow$ plasma cells \\
\hline & & Rectum & & & & & $\leftrightarrow$ neutrophils \\
\hline & & & & & & & $\leftrightarrow$ eosinophils \\
\hline \multirow[t]{3}{*}{ De Silva et $\mathrm{al}^{39}$} & 39 IBS-D DIII & Ileum & & & & & $\leftrightarrow$ neutrophils \\
\hline & $13 \mathrm{CCR}$ & Colon & & & & & $\leftrightarrow$ eosinophils \\
\hline & controls & Rectum & & & & & \\
\hline Cremon & 48 IBS" & Colon & $\uparrow * * *$ & $\uparrow *$ & $\uparrow * * *$ & $\leftrightarrow{\mathrm{B}-\mathrm{CD} 79^{+}}^{+}$ & $\uparrow * * *$ total immune cells \\
\hline et $\mathrm{a}^{22}$ & $24 \mathrm{HC}$ & & & & & & \\
\hline O'Sullivan & $14 \mathrm{IBS}^{\prime}$ & Colon & & & & & $\leftrightarrow$ lympohcytes \\
\hline \multirow[t]{3}{*}{ et $\mathrm{al}^{35}$} & $8 \mathrm{HC}$ & & & & & & $\leftrightarrow$ plasma cells \\
\hline & & & & & & & $\downarrow * * *$ neutrophils \\
\hline & & & & & & & $\leftrightarrow$ eosinophils \\
\hline \multirow[t]{4}{*}{ Piche et $\mathrm{al}^{23}$} & 50 IBS" & Colon & & & & & $\uparrow * *$ total immune cells \\
\hline & $21 \mathrm{HC}$ & & & & & & $\uparrow * *$ lymphocytes \\
\hline & & & & & & & $\leftrightarrow$ neutrophils \\
\hline & & & & & & & $\leftrightarrow$ eosinophils \\
\hline Chadwick & $38 \mathrm{IBS}^{\prime}$ & Colon & $\uparrow * * *$ & & & & $\uparrow * * *$ neutrophils \\
\hline et $\mathrm{al}^{24}$ & $28 \mathrm{HC}$ & & $\uparrow * * * \mathrm{CD}_{25} 5^{+}$ & & & & \\
\hline \multirow[t]{2}{*}{ Braak et $\mathrm{a}^{28}$} & 66 IBS" & Colon & $\leftrightarrow$ & & $\downarrow *$ & & $\downarrow \mathcal{*}^{*} \mathrm{CD} 68^{+}$macrophages \\
\hline & $20 \mathrm{HC}$ & & & & & & $\leftrightarrow \mathrm{CDI} 63^{+}$macrophages \\
\hline Forshammar & 12 IBS" & Colon & & & & $\downarrow * \lg \mathrm{A}^{+}$ & \\
\hline et $\mathrm{al}^{37}$ & II HC & & & & & & \\
\hline \multirow[t]{2}{*}{ Chang et $\mathrm{a}^{33}$} & 45 IBS" & Sigmoid & $\leftrightarrow$ & $\leftrightarrow$ & $\leftrightarrow$ & & \\
\hline & $4 \mathrm{ICC}$ & & & & & & \\
\hline \multirow[t]{2}{*}{ Akbar et $\mathrm{a}^{31}$} & 23 IBS" & Rectosigmoid & $\uparrow *$ & $\leftrightarrow$ & & & \\
\hline & $22 \mathrm{HC}$ & & & & & & \\
\hline \multirow[t]{2}{*}{ Spiller et a ${ }^{30}$} & I6 PI-IBS & Rectum & $\uparrow * * *$ & & $\uparrow * * *$ & & $\downarrow^{\mathrm{NS}} \mathrm{CD} 68^{+}$macrophages \\
\hline & $12 \mathrm{HC}$ & & & & & & \\
\hline \multirow[t]{2}{*}{ Dunlop et $\mathrm{al}^{29}$} & $28 \mathrm{PI}-\mathrm{IBS}$ & Rectum & 个** & & & & \\
\hline & $34 \mathrm{HC}$ & & & & & & \\
\hline \multirow[t]{2}{*}{ Lee et $\mathrm{al}^{36}$} & 17 IBS-D"II & Rectum & $\leftrightarrow$ & & & & \\
\hline & $12 \mathrm{HC}$ & & & & & & \\
\hline \multirow[t]{2}{*}{ Holmen et $\mathrm{a}^{27}$} & 34 IBS" & Colon & & $\leftrightarrow \mathrm{CD} 25^{+}$ & & & $\leftrightarrow \mathrm{FOXP3}$ \\
\hline & $26 \mathrm{HC}$ & Blood & & $\leftrightarrow \mathrm{CD} 25^{+}$ & & & \\
\hline \multirow[t]{2}{*}{ Kindt et $\mathrm{a}^{32}$} & $30 \mathrm{IBS}^{\prime \prime}$ & Blood & & $\leftrightarrow$ & $\leftrightarrow$ & $\leftrightarrow$ & $\leftrightarrow$ total lymphocytes \\
\hline & $32 \mathrm{HC}$ & & & & & & $\leftrightarrow$ NK-cells \\
\hline Ohman et $\mathrm{al}^{26}$ & 74 IBS" & Blood & & $\leftrightarrow$ & $\leftrightarrow$ & $\uparrow * * * \lg \mathrm{G}^{+}$ & $\leftrightarrow$ total lymphocytes \\
\hline and Ohman & $30 \mathrm{HC}$ & & & $\uparrow * * * \mathrm{CD} 9^{+}$ & $\uparrow * * * \mathrm{CD}^{2} 9^{+}$ & $\uparrow * * \mathrm{CD} 80^{+}$ & \\
\hline \multirow[t]{5}{*}{ et $\mathrm{a}^{38}$} & & & & $\uparrow * * * \beta 7^{+} \mathrm{HLA}-$ & $\uparrow * \beta 7^{+} \mathrm{HLA}-$ & $\uparrow * * \mathrm{CD}^{+} 6^{+}$ & \\
\hline & & & & $\mathrm{DR}^{+}$ & $\mathrm{DR}^{+}$ & $\uparrow * * \beta 7^{+} \mathrm{CD} 80^{+}$ & \\
\hline & & & & $\leftrightarrow \mathrm{CD} 25^{+}$ & $\leftrightarrow \mathrm{CD} 25^{+}$ & $\uparrow * * * \beta 7^{+} \mathrm{CD} 86^{+}$ & \\
\hline & & & & & & $\downarrow * *$ HLA-DR ${ }^{+}$ & \\
\hline & & & & & & $\downarrow * * \mathrm{CD} 40^{+}$ & \\
\hline
\end{tabular}

Notes: aDiagnostic criteria ('Rome I, "Rome II, "'Rome III); 'expression ( $\uparrow$ Increased, $\downarrow$ Decreased, $\leftrightarrow$ no difference; compared with HC); 'significance (*P $<0.05$; $* * P<0.0$ I; $* * * P<0.001$, Ns not significant).

Abbreviations: CCR controls, individuals with family history of colorectal cancer; HC, healthy control; IBS, irritable bowel syndrome; IBS-D, IBS with diarrhea predominance; PI-IBS, post-infectious IBS.

The study of mast cells in IBS by various groups has produced rather consistent results, suggesting a role of these cells in the pathobiology of IBS (Table 2). Specifically, a greater number of mast cells have been described primarily in patients with IBS-D. ${ }^{34}$ Mast cells are primarily localized in the duodenum, jejunum, and terminal ileum, followed by the rectum, while in the colon they are less abundant. This distribution might explain why some studies failed to detect an increase in mast cells in the colonic mucosa of patients with IBS $33,35,41$ while other studies succeeded. ${ }^{22-24,34,39,42,43}$ In 
Table 2 Mast cells and IBS

\begin{tabular}{|c|c|c|c|c|c|c|}
\hline Study & $\mathbf{N}^{\mathrm{a}}$ & $\begin{array}{l}\text { Anatomic } \\
\text { location }\end{array}$ & $\begin{array}{l}\text { Mast } \\
\text { cells }^{\mathrm{b}, \mathrm{c}}\end{array}$ & $\begin{array}{l}\mathrm{EE} / \mathrm{EC} \\
\text { cells } s^{\mathrm{b}, \mathrm{c}}\end{array}$ & Soluble mediators ${ }^{b, c}$ & $\begin{array}{l}\text { Correlation } \\
\text { with symptoms, }\end{array}$ \\
\hline \multirow[t]{2}{*}{ Foley et $\mathrm{a}^{45}$} & 20 IBS-D"II & Duodenum & $\uparrow * * *$ & $\leftrightarrow$ & $\uparrow *$ tryptase & $\uparrow *$ depression \\
\hline & $29 \mathrm{HC}$ & & & & & $\uparrow *$ anxiety \\
\hline \multirow[t]{2}{*}{ Guilarte et $\mathrm{a}^{16}$} & 20 IBS-D" & Jejunum & $\uparrow * * *$ & & $\uparrow * *$ tryptase & \\
\hline & $14 \mathrm{HC}$ & & & & & \\
\hline \multirow[t]{3}{*}{ Martinez et al ${ }^{48}$} & 25 IBS-D" & Jejunum & $\uparrow * *$ & & $\uparrow * * *$ tryptase & $\leftrightarrow$ abdominal pain \\
\hline & $23 \mathrm{HC}$ & & & & & $\uparrow *$ bowel movements \\
\hline & & & & & & $\uparrow *$ stool consistency \\
\hline \multirow[t]{2}{*}{ Wang et a $\left.\right|^{54}$} & 38 IBS & Terminal ileum & $\uparrow * * *$ & $\leftrightarrow$ & & \\
\hline & $18 \mathrm{HC}$ & & & & & \\
\hline \multirow[t]{4}{*}{ De Silva et a ${ }^{39}$} & 39 IBS-D"III & Ileum & $\uparrow * * *$ & & & \\
\hline & 13 CCR & Cecum & $\uparrow * * *$ & & & \\
\hline & controls & Colon & $\uparrow *$ & & & \\
\hline & & Rectum & $\uparrow * * *$ & & & \\
\hline \multirow[t]{3}{*}{ Park et a $\left.\right|^{34}$} & I8 IBS-D"| & Terminal ileum & $\uparrow * *$ & & & $\downarrow *$ rectal sensitivity \\
\hline & $15 \mathrm{HC}$ & Colon & $\uparrow * *$ & & & \\
\hline & & Rectum & $\uparrow * *$ & & & \\
\hline \multirow[t]{2}{*}{ Weston et $\mathrm{al}^{41}$} & $20 \mathrm{IBS}^{\mathrm{IV}}$ & Terminal ileum & $\uparrow * * *$ & & & \\
\hline & $\mathrm{I} 5 \mathrm{HC}$ & Colon & $\leftrightarrow$ & & & \\
\hline \multirow[t]{2}{*}{ Cremon et $\mathrm{a}^{22}$} & 48 IBS" & Colon & $\uparrow * * *$ & & & $\uparrow *$ abdominal bloating \\
\hline & $24 \mathrm{HC}$ & & & & & $\uparrow * * *$ dyspepsia \\
\hline \multirow[t]{2}{*}{ Cremon et $\mathrm{al}^{47}$} & $25 \mathrm{IBS}^{\prime \prime}$ & Colon & $\uparrow * *$ & $\uparrow *$ & $\uparrow * * *$ serotonin & $\uparrow *$ abdominal pain \\
\hline & $12 \mathrm{HC}$ & & & & & severity \\
\hline \multirow[t]{2}{*}{ Piche et $\mathrm{a}^{23}$} & $50 \mathrm{IBS}^{\prime \prime}$ & Colon & $\uparrow * * *$ & & & $\uparrow * * *$ fatigue \\
\hline & $21 \mathrm{HC}$ & & & & & $\uparrow *$ depression \\
\hline \multirow[t]{2}{*}{ Chadwick et al ${ }^{24}$} & $38 \mathrm{IBS}^{\prime}$ & Colon & $\uparrow * * *$ & & & \\
\hline & $28 \mathrm{HC}$ & & & & & \\
\hline \multirow[t]{3}{*}{ Buhner et $\mathrm{al}^{42}$} & I8 IBS" & Colon & $\uparrow * *$ & & $\uparrow * * *$ tryptase & \\
\hline & $7 \mathrm{HC}$ & & & & $\uparrow * *$ histamine & \\
\hline & & & & & $\leftrightarrow$ serotonin & \\
\hline Barbara et $\mathrm{a}^{43}$ & 44 IBS" & Colon & $\uparrow$ & & $\uparrow *$ tryptase & $\uparrow * *$ abdominal pain when \\
\hline and Barbara et $\mathrm{al}^{52}$ & $22 \mathrm{HC}$ & & & & $\uparrow *$ histamine & proximal to nerves \\
\hline \multirow[t]{2}{*}{ Braak et $\mathrm{a}^{28}$} & 66 IBS" & Colon & $\downarrow * * *$ & & & $\leftrightarrow$ rectal sensitivity \\
\hline & $20 \mathrm{HC}$ & & & & & \\
\hline \multirow[t]{2}{*}{ Klooker et a ${ }^{44}$} & 60 IBS" & Rectum & $\downarrow *$ & & $\leftrightarrow$ tryptase & $\leftrightarrow$ rectal sensitivity \\
\hline & $22 \mathrm{HC}$ & & & & $\leftrightarrow$ histamine & \\
\hline \multirow[t]{2}{*}{ Chang et $\mathrm{a}^{33}$} & 45 IBS" & Sigmoid & $\leftrightarrow$ & $\leftrightarrow$ & & $\leftrightarrow$ \\
\hline & $4 \mathrm{ICC}$ & & & & & \\
\hline \multirow[t]{2}{*}{ O'Sullivan et al ${ }^{35}$} & I4 IBS' & Colon & $\leftrightarrow$ & & & \\
\hline & $7 \mathrm{HC}$ & Rectum & $\leftrightarrow$ & & & \\
\hline \multirow[t]{2}{*}{ Akbar et $\mathrm{al}^{31}$} & 23 IBS" & Rectosigmoid & $\uparrow *$ & & & \\
\hline & $22 \mathrm{HC}$ & & & & & \\
\hline \multirow[t]{2}{*}{ Spiller et a $\left.\right|^{30}$} & 16 PI-IBS & Rectum & $\leftrightarrow$ & $\uparrow * * *$ & & \\
\hline & $12 \mathrm{HC}$ & & & & & \\
\hline \multirow[t]{2}{*}{ Dunlop et $\mathrm{al}^{29}$} & $28 \mathrm{PI}-\mathrm{IBS}$ & Rectum & $\leftrightarrow$ & $\uparrow * *$ & & $\uparrow *$ depression \\
\hline & $34 \mathrm{HC}$ & & & & & \\
\hline \multirow[t]{2}{*}{ Lee et $\mathrm{al}^{36}$} & 17 IBS-D"II & Rectum & $\uparrow *$ & $\leftrightarrow$ & & $\leftrightarrow$ anxiety \\
\hline & $12 \mathrm{HC}$ & & & & & $\leftrightarrow$ depression \\
\hline Corinaldesi et $\mathrm{al}^{88}$ & I0 IBS"-placebo & Colon & & & & $\downarrow * *$ response to \\
\hline & group & & & & & treatment \\
\hline & I0 IBS-mesalazine & & & & & \\
\hline & group & & & & & \\
\hline
\end{tabular}

Notes: aDiagnostic criteria ('Rome I, "Rome II, "'Rome III, 'VManning); ' expression ( $\uparrow$ Increased, $\downarrow$ Decreased, $\leftrightarrow$ no difference; compared with HC); ' significance ( ${ }^{*} P<0.05$; $* * P<0.01$; *** $P<0.001$ ).

Abbreviations: CCR controls, individuals with family history of colorectal cancer; EE, enteroendocrine; EC, enterochromaffin; HC, healthy control; IBS, irritable bowel syndrome; IBS-D, IBS with diarrhea predominance; PI-IBS, post-infectious IBS. 
contrast to the rest of the studies, Braak et $\mathrm{al}^{28}$ and Klooker et $\mathrm{al}^{44}$ reported a decrease in the number of mast cells in the colonic and rectal mucosa, respectively, of patients with IBS.

In several reports, the increase in mast cells was associated with higher release of their soluble mediators tryptase, histamine and serotonin. ${ }^{42,43,45-47}$ Moreover, there were some positive correlations between mast cells and depression, anxiety, fatigue $^{23}$ and IBS symptoms such as abdominal pain, bloating, and bowel habits, ${ }^{48}$ in particular when activated mast cells were found in proximity to the enteric neurons. ${ }^{34,43}$ However, studies examining the number of mast cells in relation to visceral sensitivity, as measured by the barostat test, found a negative correlation with visceral hypersensitivity. ${ }^{34,44}$

Mediators secreted by mast cells in feces or the luminal fluid have also been proposed as biomarkers for IBS. In a group of 38 IBS patients, Roka et $\mathrm{al}^{49}$ found that compared to 15 healthy controls, fecal serine-protease activity was threefold higher in the IBS-D subgroup, but not in IBS-C or IBS-M. However, this increase did not correlate with the frequency of bowel movements in a subsequent study. ${ }^{50}$ In contrast, Lettesjo et $\mathrm{al}^{51}$ found that fecal tryptase levels were not different between a group of 46 IBS patients and 20 healthy controls. The significance of mast cell mediators in IBS is better illustrated by studies in which supernatants from colonic mucosa biopsies of patients with IBS, but not controls, were able to activate rat, mouse, and human sensory neurons in vitro ${ }^{42,52}$ and induce somatic and visceral hyperalgesia and allodynia when administered into the colon of mice. ${ }^{53}$ The use of pharmacological antagonists in the above mentioned studies revealed that these effects were mediated primarily by proteases, and also by histamine and serotonin.

Some of the studies that report increased numbers of mast cells in the intestinal mucosa of patients with IBS determined also the number of enterochromaffin and enteroendocrine cells and found them unaltered ${ }^{36,45,54}$ or increased. ${ }^{22}$ Interestingly, Spiller et $\mathrm{al}^{30}$ found an increased number of enteroendocrine cells, and Dunlop et $\mathrm{al}^{55}$ an increased number of enterochromaffin (5-HT positive) cells in the rectal mucosa of patients with PI-IBS, albeit a similar number of mast cells.

In an analogy to the mast cell mediators, members of the chromogranin family (chromogranins A $[\mathrm{CgA}]$ and $\mathrm{B}[\mathrm{CgB}]$ and secretogranins) are the major components found in the secretory granules of enteroendocrine cells. ${ }^{56}$ Based on the study of 82 patients with IBS and 29 controls by Ohman et al, ${ }^{57}$ while fecal levels of $\mathrm{CgB}$ were lower than controls, fecal levels of CgA, SgII, and SgIII were significantly increased in IBS patients and had a positive correlation with perceived severity of abdominal pain and a negative correlation with colonic transit times.

\section{Cytokines as biomarkers in IBS}

In addition to their immunomodulatory role, various cytokines are also involved in the control of gastrointestinal functions, including motility and visceral sensitivity, although their specific role in IBS is not fully elucidated. ${ }^{58-61}$ Intestinal mucosal biopsies, serum, and blood cells isolated and cultured ex vivo, have been used to examine the significance of cytokines in IBS (Table 3). Overall, results are not consistent between the various studies, primarily due to differences in the source of cytokines (mucosa versus serum versus peripheral blood cells), the type of IBS (most changes in cytokines have been described in PI-IBS and in patients with IBS-D), and the presence of various comorbidities. In the plasma of IBS patients, upregulation of interleukin (IL)-6 and IL-8 levels were reported in four different studies. ${ }^{62-64}$ Importantly, Scully et $\mathrm{al}^{62}$ found increased plasma levels of IL-1 $\beta$ and tumor necrosis factor (TNF)- $\alpha$ in a group of women with IBS and comorbidities such as fibromyalgia, premenstrual dysmorphic disorder, or chronic fatigue syndrome. Other groups report increased secretion of IL- $1 \beta$, IL- 8 , and TNF- $\alpha$ by peripheral blood mononuclear cells (PBMCs) of patients with IBS. ${ }^{26,64-66}$

Chen et $\mathrm{ll}^{67}$ studied the mRNA levels of several cytokines in the colonic mucosa of patients with PI-IBS and found upregulation of interferon- $\gamma$ and downregulation of IL-10, while Chang et $\mathrm{al}^{33}$ found lower IL-10 expression only in female patients with IBS. Likewise, McSharry et $\mathrm{al}^{68}$ reported lower levels of IL-10 in female patients with IBS but also decreased IL-1 $\beta$. In conclusion, the most consistent finding in the studies of mucosal cytokine expression appears to be lower IL-10. $33,67,68$

More recent studies have associated polymorphisms in several cytokine genes with susceptibility to IBS. ${ }^{69,70}$ Among them, a single nucleotide polymorphism (SNP) in the TL1A gene (TNFSF 15) increases the risk for IBS-D and IBS-C by 1.4- and 1.8-fold, respectively according to two independent case-control studies of a total of 1992 individuals. ${ }^{71}$ These findings have been replicated by different groups in a smaller number of patients with IBS. ${ }^{72,73}$ Accordingly, increased TL1A expression has been described in the mucosa of patients with IBS compared with controls. ${ }^{73}$ Associations of two TNF- $\alpha$ SNPs and susceptibility to IBS have also been described 
Gras-Miralles and Kokkotou

Dovepress

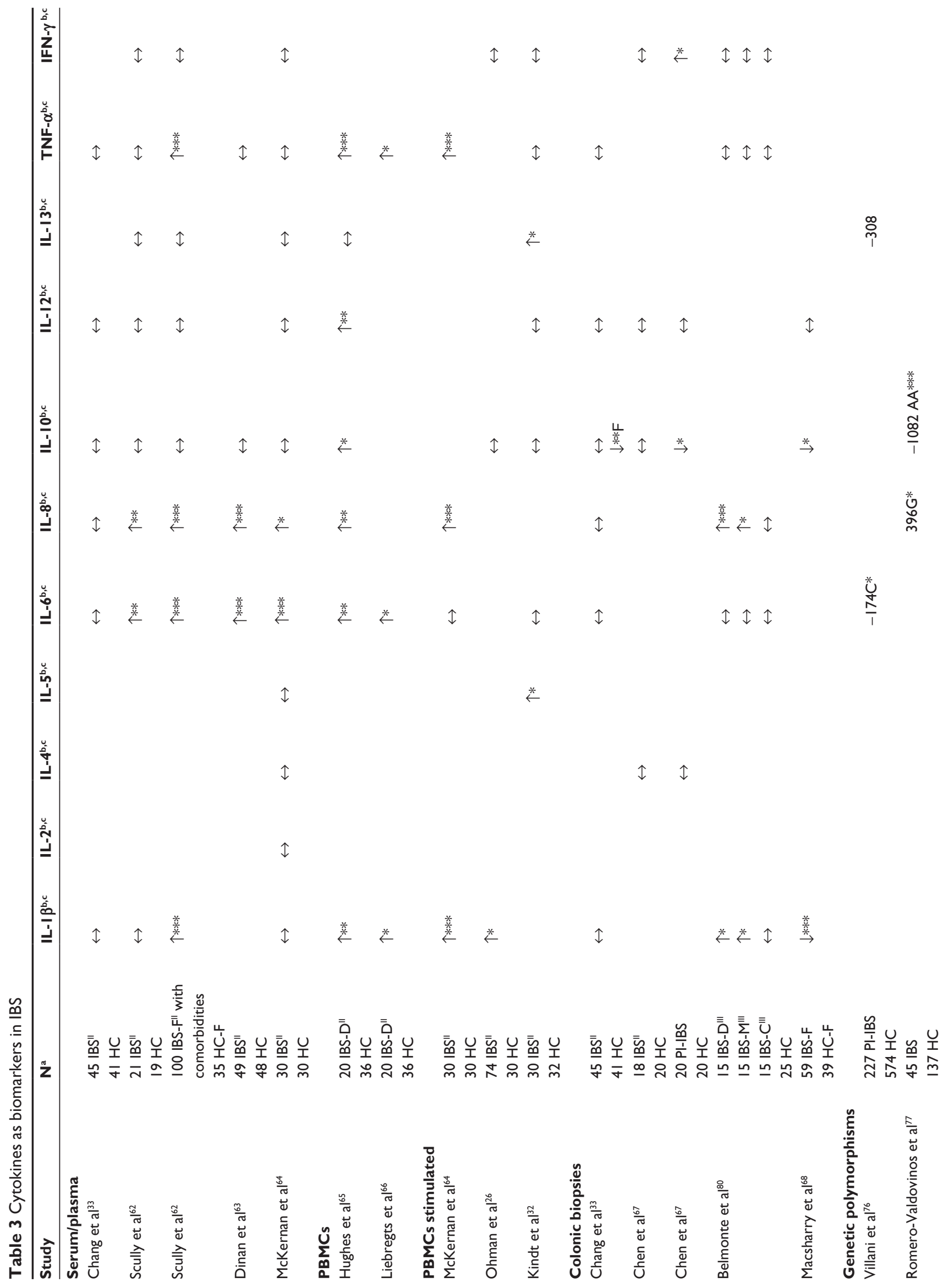

48

submit your manuscript | www.dovepress.com

Current Biomarker Findings 2013:3

Dovepress 


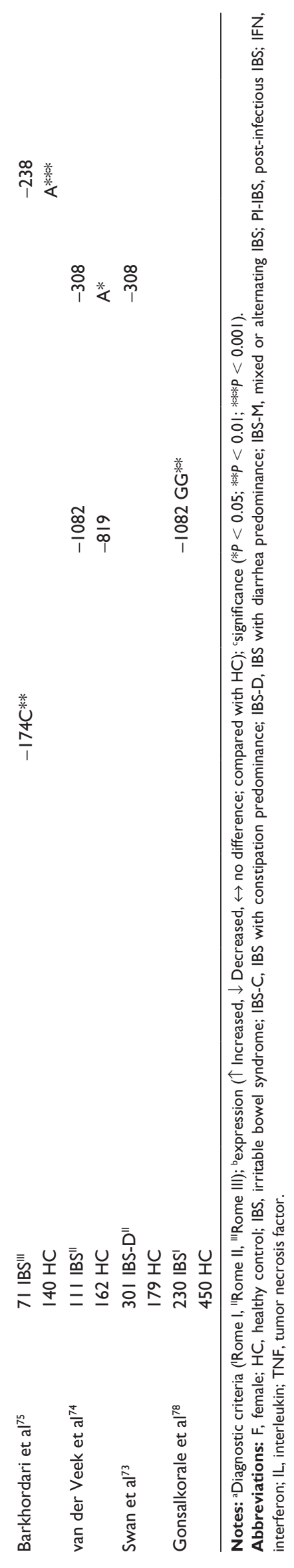

in a Dutch ${ }^{74}$ and an Iranian ${ }^{75}$ population. Polymorphisms in additional cytokine genes, including $I L-6,{ }^{75,76} I L-8,{ }^{77}$ and $I L-10^{74,77,78}$ have been linked to IBS in various studies, each of which, however, included a relative small number of IBS patients and controls. Notably, some of the above SNPs, ie, in $I L-10, T N F-\alpha$, and $T L 1 A$ are associated with susceptibility to Crohn's disease and ulcerative colitis, perhaps suggesting disease pathophysiology mechanisms shared by IBS and IBD. $^{72,73}$

\section{Non-cytokine immune modulators as biomarkers in IBS}

Toll-like receptors (TLRs) are a family of pathogen-recognition molecules with a central role in mucosal innate immune responses. In IBS patients, Brint et al ${ }^{79}$ described increased colonic expression of TLR4 and TLR5, lower expression of TLR7 and TLR8, and no differences in the rest of the TLR receptors examined (Table 4). In the study by Belmonte et al, ${ }^{80}$ TLR 2 and TLR4 upregulation was found predominantly in the IBS-M subgroup. In a larger cohort of IBS patients, Ohman et $a l^{81}$ examined TLR2 and TLR4 expression in blood monocytes and found only TLR 2 to be increased. Finally, in the Walkerton Health Study for clinical and genetic predictors of developing IBS within 2-3 years following an episode of acute gastroenteritis, Villani et $\mathrm{al}^{76}$ identified the rs5743936:T variant of TLR9 (the receptor which mediates the recognition of bacterial unmethylated $\mathrm{CpG}$ dinucleotides) as an independent risk factor for PI-IBS. In a different population, rs5743936: T was found to be a risk allele for IBS-D by Camilleri et al. ${ }^{72}$ McKernan et $\mathrm{a}^{64}$ studied IL-1 $\beta$, IL-6, IL-8, and TNF- $\alpha$ release from PBMCs in response to stimulation with specific TLR agonists. Their results indirectly suggested increased TLR $2,3,4,5,7$, and in particular TLR8 signaling activity, but no differences in TLR1, TLR6, or TLR9 (Table 4). Taken together, the above observations further support a role of host-microbial interactions in the pathogenesis of IBS.

From a different perspective, Schoepfer et $\mathrm{a}^{82}$ found an increased frequency of antibodies against flagellin, the structural protein in bacterial flagellae that is recognized by TLR5, in the serum of 112 patients with IBS when compared with 43 controls.

In addition to bacterial recognition through TLRs, an important host defense mechanism relies on the secretion by intestinal epithelial cells of various antimicrobial peptides such as defensins. ${ }^{83}$ Human beta-defensin-2 (hBD2) 
Table 4 Toll-like receptors in IBS

\begin{tabular}{|c|c|c|c|c|c|c|c|c|c|c|c|c|}
\hline Study & $\mathbf{N}^{\mathbf{a}}$ & Source & TLR $\left.\right|^{b, c}$ & TLR2 $^{\mathrm{b}, \mathrm{c}}$ & TLR3 $^{\mathrm{b}, \mathrm{c}}$ & TLR4 $^{\mathrm{b}, \mathrm{c}}$ & TLR5 $^{\mathrm{b}, \mathrm{c}}$ & TLR6 ${ }^{\mathrm{b}, \mathrm{c}}$ & TLR7 $^{\mathrm{b}, \mathrm{c}}$ & TLR8 $^{\mathrm{b}, \mathrm{c}}$ & TLR9b,c & TLR I $0^{\mathrm{b}, \mathrm{c}}$ \\
\hline \multirow[t]{2}{*}{ Brint et al ${ }^{79}$} & 26-IBS-F & Colonic & $\leftrightarrow$ & $\leftrightarrow$ & $\leftrightarrow$ & $\uparrow * * *$ & $\uparrow * *$ & $\leftrightarrow$ & $\downarrow * * *$ & $\downarrow * *$ & $\leftrightarrow$ & $\leftrightarrow$ \\
\hline & I9-HC-F & mucosa & & & & & & & & & & \\
\hline Belmonte & I5 IBS-D 3 & Colonic & & $\leftrightarrow$ & & $\leftrightarrow$ & & & & & & \\
\hline \multirow[t]{3}{*}{ et $\mathrm{a}^{80}$} & 14 IBS-M ${ }^{3}$ & mucosa & & $\uparrow *$ & & $\uparrow *$ & & & & & & \\
\hline & 13 IBS-C ${ }^{3}$ & & & $\leftrightarrow$ & & $\leftrightarrow$ & & & & & & \\
\hline & $25 \mathrm{HC}$ & & & & & & & & & & & \\
\hline Ohman & $74 \mathrm{IBS}^{2}$ & Monocytes & & $\uparrow *$ & & $\leftrightarrow$ & & & & & & \\
\hline et $\mathrm{al}^{81}$ & $30 \mathrm{HC}$ & & & & & & & & & & & \\
\hline Villani & 227 PI-IBS & SNPs & & & & & & & & & $-1237 T^{*}$ & \\
\hline et $\mathrm{al}^{76}$ & $574 \mathrm{HC}$ & & & & & & & & & & & \\
\hline Camilleri & I 75 IBS-D² & SNPs & & & & & & & & & $-1237 T^{*}$ & \\
\hline et $\mathrm{al}^{72}$ & $233 \mathrm{HC}$ & & & & & & & & & & & \\
\hline
\end{tabular}

Notes: ${ }^{a}$ Diagnostic criteria ("Rome II, "'Rome III); ${ }^{b}$ expression ( $\uparrow$ Increased, $\downarrow$ Decreased, $\leftrightarrow$ no difference; compared with HC); ${ }^{c}$ significance $(* P<0.05 ; * * P<0.0$ I; $* * * P<0.001)$.

Abbreviations: F, female; HC, healthy control; IBS, irritable bowel syndrome; IBS-C, IBS with constipation predominance; IBS-D, IBS with diarrhea predominance; IBS-M, mixed or alternating IBS; PI-IBS, post-infectious IBS; SNP, single nucleotide polymorphism; TLR, Toll-like receptor.

is constitutively expressed, while hBD2, -3 and -4 , only in response to inflammation or infection. ${ }^{84,85}$ Langhorst et a ${ }^{83}$ described increased levels of beta defensin-2 (hBD2) in the feces of 46 patients with IBS ( 24 with IBS-D and 22 with IBS-M) compared with 24 controls.

\section{Biomarkers of response to treatment in IBS}

The choice of a primary endpoint for a clinical trial is one of the most important determinants of the ability to demonstrate therapeutic efficacy. ${ }^{86}$ This is even more so for diseases like IBS, which currently depend on patient-reported subjective outcomes. Only few studies have addressed immune biomarkers in relation to response to treatment in IBS. O'Mahony et $a l^{87}$ reported changes in IL-10 and IL-12 secretion from unstimulated PBMCs in IBS patients treated with a probiotic. In the study by Corinaldesi et $a 1,{ }^{88}$ treatment of ten patients with IBS with mesalazine resulted in a significant reduction of mast cells in their colonic mucosa compared with placebo-treated patients, suggesting that mast cells could perhaps represent a marker for disease monitoring as well as a therapeutic target in IBS. Indeed, in another report treatment of 60 IBS patients with the mast cell stabilizer ketotifen decreased visceral hypersensitivity and improved their clinical symptoms. ${ }^{44}$ Our own studies revealed an association between changes in serum levels of osteoprotegerin, TNFlike weak inducer of apoptosis (TWEAK), and symptom improvement in patients with IBS who received a placeboacupuncture intervention. ${ }^{89}$ Osteoprotegerin and TWEAK are both members of the TNF superfamily (TNFRSF11B and TNFSF12, respectively) with pleiotropic immunemodulatory effects.

\section{Summary of findings}

The major points of this review are summarized as follows:

- Several studies have demonstrated increased number or activation of mast cells in the intestine of patients with IBS, in particular in those with IBS-D.

- A chronic state of low -grade subclinical inflammation characterizes IBS. This might be the result of an imbalanced host response to the gut microbiome, triggered by a pathogen, as is the case of PI-IBS, and accentuated by genetic factors. This notion is supported by altered expression in IBS of various cytokines (IL-1 $\beta$, IL-6, IL-8, IL-10, TNF- $\alpha$ ) and toll-like receptors. Single nucleotide polymorphisms in the above genes have been associated with altered susceptibility to IBS.

\section{Conclusion and perspectives}

The main conclusions of this review are the following:

- There is not enough evidence for immune biomarkers described so far in IBS studies to be used as diagnostic or disease monitoring tools. Lack of consensus among the various studies might be attributed to small number of patients included, disease heterogeneity, presence of comorbidities, focus on intestinal versus fecal versus blood biomarkers, and variations in tissue sampling and experimental design.

- Immune biomarkers have greatly contributed to our understanding of various aspects of IBS pathophysiology. Moreover, certain immune biomarkers correlate with disease subgroups, raising the intriguing possibility of distinct mechanisms underlying the different IBS subtypes. 
- In some cases the identified biomarkers have suggested new therapeutic approaches for IBS, for instance, treatment with probiotics or mast cell stabilizers.

It is our belief that recent advances in high throughput technologies, including genomics, proteomics, metabolomics, and microbiome analysis, or their various combinations, corroborated by powerful bioinformatics approaches and when applied to a large number of well-characterized IBS patients, will lead to the unbiased development of robust biomarkers for disease diagnosis and treatment outcomes. Moreover, categorization of patients according to certain immune/genetic profiles might lead to more effective and personalized treatments.

\section{Acknowledgments}

This review has been supported by NIH grants R01AT004662 and R01DK080058.

\section{Disclosure}

The authors report no conflicts of interest in this work.

\section{References}

1. Longstreth GF, Thompson WG, Chey WD, Houghton LA, Mearin F, Spiller RC. Functional bowel disorders. Gastroenterology. 2006;130(5):1480-1491.

2. Drossman DA, Dumitrascu DL. Rome III: new standard for functional gastrointestinal disorders. J Gastrointestin Liver Dis. 2006;15(3):237-241.

3. Spiller RC. Postinfectious irritable bowel syndrome. Gastroenterology. 2003;124(6):1662-1671

4. Neal KR, Hebden J, Spiller R. Prevalence of gastrointestinal symptoms six months after bacterial gastroenteritis and risk factors for development of the irritable bowel syndrome: postal survey of patients. $B M J$. 1997;314(7083):779-782.

5. Spiller R, Lam C. An Update on post-infectious irritable bowel syndrome: role of genetics, immune activation, serotonin and altered microbiome. J Neurogastroenterol Motil. 2012;18(3): 258-268.

6. Gwee KA, Graham JC, McKendrick MW, et al. Psychometric scores and persistence of irritable bowel after infectious diarrhoea. Lancet. 1996;347(8995):150-153.

7. Marshall JK, Thabane M, Garg AX, Clark WF, Salvadori M, Collins SM. Incidence and epidemiology of irritable bowel syndrome after a large waterborne outbreak of bacterial dysentery. Gastroenterology. 2006;131(2):445-450; quiz 660.

8. Spiller R, Garsed K. Postinfectious irritable bowel syndrome. Gastroenterology. 2009;136(6):1979-1988.

9. Lovell RM, Ford AC. Global prevalence of and risk factors for irritable bowel syndrome: a meta-analysis. Clin Gastroenterol Hepatol. 2012; 10(7):712-721. e4.

10. Talley NJ, Zinsmeister AR, Van Dyke C, Melton LJ 3rd. Epidemiology of colonic symptoms and the irritable bowel syndrome. Gastroenterology. 1991;101(4):927-934.

11. Russo MW, Gaynes BN, Drossman DA. A national survey of practice patterns of gastroenterologists with comparison to the past two decades. J Clin Gastroenterol. 1999;29(4):339-343.

12. Martin R, Barron JJ, Zacker C. Irritable bowel syndrome: toward a costeffective management approach. Am J Manag Care. 2001;7(Suppl 8): S268-S275.
13. Sandler RS, Everhart JE, Donowitz M, et al. The burden of selected digestive diseases in the United States. Gastroenterology. 2002;122(5):1500-1511.

14. American Gastroenterological Association. The Burden of Gastrointestinal Diseases: 2001. Bethesda, MD: American Gastroenterological Association; 2001:1-86.

15. Chang L. Review article: epidemiology and quality of life in functional gastrointestinal disorders. Aliment Pharmacol Ther. 2004;20 Suppl 7: 31-39.

16. Spiegel BM, Farid M, Esrailian E, Talley J, Chang L. Is irritable bowel syndrome a diagnosis of exclusion?: a survey of primary care providers, gastroenterologists, and IBS experts. Am J Gastroenterol. 2010;105(4): 848-858.

17. Katz R. Biomarkers and surrogate markers: an FDA perspective. NeuroRx. 2004;1(2):189-195.

18. Clarke G, Quigley EM, Cryan JF, Dinan TG. Irritable bowel syndrome: towards biomarker identification. Trends Mol Med. 2009;15(10): 478-489.

19. Lembo AJ, Neri B, Tolley J, Barken D, Carroll S, Pan H. Use of serum biomarkers in a diagnostic test for irritable bowel syndrome. Aliment Pharmacol Ther. 2009;29(8):834-842.

20. Ford AC, Talley NJ. Mucosal inflammation as a potential etiological factor in irritable bowel syndrome: a systematic review. J Gastroenterol. 2011;46(4):421-431.

21. Spiller R, Lam C. The shifting interface between IBS and IBD. Curr Opin Pharmacol. 2011;11(6):586-592.

22. Cremon C, Gargano L, Morselli-Labate AM, et al. Mucosal immune activation in irritable bowel syndrome: gender-dependence and association with digestive symptoms. Am J Gastroenterol. 2009;104(2):392-400.

23. Piche T, Saint-Paul MC, Dainese R, et al. Mast cells and cellularity of the colonic mucosa correlated with fatigue and depression in irritable bowel syndrome. Gut. 2008;57(4):468-473.

24. Chadwick VS, Chen W, Shu D, et al. Activation of the mucosal immune system in irritable bowel syndrome. Gastroenterology. 2002;122(7):1778-1783.

25. Ohman L, Isaksson S, Lundgren A, Simren M, Sjovall H. A controlled study of colonic immune activity and beta7+ blood $\mathrm{T}$ lymphocytes in patients with irritable bowel syndrome. Clin Gastroenterol Hepatol. 2005;3(10):980-986.

26. Ohman L, Isaksson S, Lindmark AC, et al. T-cell activation in patients with irritable bowel syndrome. Am J Gastroenterol. 2009;104(5):1205-1212.

27. Holmen N, Isaksson S, Simren M, Sjovall H, Ohman L. $\mathrm{CD} 4+\mathrm{CD} 25+$ regulatory $\mathrm{T}$ cells in irritable bowel syndrome patients. Neurogastroenterol Motil. 2007;19(2):119-125.

28. Braak B, Klooker TK, Wouters MM, et al. Mucosal immune cell numbers and visceral sensitivity in patients with irritable bowel syndrome: is there any relationship? Am J Gastroenterol. 2012;107(5): 715-726.

29. Dunlop SP, Jenkins D, Spiller RC. Distinctive clinical, psychological, and histological features of postinfective irritable bowel syndrome. Am J Gastroenterol. 2003;98(7):1578-1583.

30. Spiller RC, Jenkins D, Thornley JP, et al. Increased rectal mucosal enteroendocrine cells, T lymphocytes, and increased gut permeability following acute Campylobacter enteritis and in post-dysenteric irritable bowel syndrome. Gut. 2000;47(6):804-811.

31. Akbar A, Yiangou Y, Facer P, Walters JR, Anand P, Ghosh S. Increased capsaicin receptor TRPV1-expressing sensory fibres in irritable bowel syndrome and their correlation with abdominal pain. Gut. 2008;57(7): 923-929.

32. Kindt S, Van Oudenhove L, Broekaert D, et al. Immune dysfunction in patients with functional gastrointestinal disorders. Neurogastroenterol Motil. 2009;21(4):389-398.

33. Chang L, Adeyemo M, Karagiannides I, et al. Serum and colonic mucosal immune markers in irritable bowel syndrome. Am J Gastroenterol. 2012;107(2):262-272. 
34. Park JH, Rhee PL, Kim HS, et al. Mucosal mast cell counts correlate with visceral hypersensitivity in patients with diarrhea predominant irritable bowel syndrome. J Gastroenterol Hepatol. 2006;21(1 Pt 1): 71-78.

35. O'Sullivan M, Clayton N, Breslin NP, et al. Increased mast cells in the irritable bowel syndrome. Neurogastroenterol Motil. 2000;12(5): 449-457.

36. Lee KJ, Kim YB, Kim JH, Kwon HC, Kim DK, Cho SW. The alteration of enterochromaffin cell, mast cell, and lamina propria T lymphocyte numbers in irritable bowel syndrome and its relationship with psychological factors. J Gastroenterol Hepatol. 2008;23(11):1689-1694.

37. Forshammar J, Isaksson S, Strid H, et al. A pilot study of colonic B cell pattern in irritable bowel syndrome. Scand J Gastroenterol. 2008;43(12):1461-1466.

38. Ohman L, Lindmark AC, Isaksson S, et al. B-cell activation in patients with irritable bowel syndrome (IBS). Neurogastroenterol Motil. 2009;21(6):644-650. e27.

39. De Silva AP, Nandasiri SD, Hewavisenthi J, et al. Subclinical mucosal inflammation in diarrhea-predominant irritable bowel syndrome (IBS) in a tropical setting. Scand J Gastroenterol. 2012;47(6):619-624.

40. Barbara G, Stanghellini V, De Giorgio R, Corinaldesi R. Functional gastrointestinal disorders and mast cells: implications for therapy. Neurogastroenterol Motil. 2006;18(1):6-17.

41. Weston AP, Biddle WL, Bhatia PS, Miner PB Jr. Terminal ileal mucosal mast cells in irritable bowel syndrome. Dig Dis Sci. 1993;38(9): 1590-1595.

42. Buhner S, Li Q, Vignali S, et al. Activation of human enteric neurons by supernatants of colonic biopsy specimens from patients with irritable bowel syndrome. Gastroenterology. 2009;137(4):1425-1434.

43. Barbara G, Stanghellini V, De Giorgio R, et al. Activated mast cells in proximity to colonic nerves correlate with abdominal pain in irritable bowel syndrome. Gastroenterology. 2004;126(3):693-702.

44. Klooker TK, Braak B, Koopman KE, et al. The mast cell stabiliser ketotifen decreases visceral hypersensitivity and improves intestinal symptoms in patients with irritable bowel syndrome. Gut. 2010;59(9): 1213-1221.

45. Foley S, Garsed K, Singh G, et al. Impaired uptake of serotonin by platelets from patients with irritable bowel syndrome correlates with duodenal immune activation. Gastroenterology. 2011;140(5):14341443. e1.

46. Guilarte M, Santos J, de Torres I, et al. Diarrhoea-predominant IBS patients show mast cell activation and hyperplasia in the jejunum. Gut. 2007;56(2):203-209.

47. Cremon C, Carini G, Wang B, et al. Intestinal serotonin release, sensory neuron activation, and abdominal pain in irritable bowel syndrome. Am J Gastroenterol. 2011;106(7):1290-1298.

48. Martinez C, Vicario M, Ramos L, et al. The jejunum of diarrheapredominant irritable bowel syndrome shows molecular alterations in the tight junction signaling pathway that are associated with mucosal pathobiology and clinical manifestations. Am J Gastroenterol. 2012; 107(5):736-746.

49. Roka R, Rosztoczy A, Leveque M, et al. A pilot study of fecal serineprotease activity: a pathophysiologic factor in diarrhea-predominant irritable bowel syndrome. Clin Gastroenterol Hepatol. 2007;5(5): $550-555$.

50. Gecse K, Roka R, Ferrier L, et al. Increased faecal serine protease activity in diarrhoeic IBS patients: a colonic lumenal factor impairing colonic permeability and sensitivity. Gut. 2008;57(5):591-599.

51. Lettesjo H, Hansson T, Peterson C, et al. Detection of inflammatory markers in stools from patients with irritable bowel syndrome and collagenous colitis. Scand J Gastroenterol. 2006;41(1):54-59.

52. Barbara G, Wang B, Stanghellini V, et al. Mast cell-dependent excitation of visceral-nociceptive sensory neurons in irritable bowel syndrome. Gastroenterology. 2007;132(1):26-37.

53. Cenac N, Andrews CN, Holzhausen M, et al. Role for protease activity in visceral pain in irritable bowel syndrome. J Clin Invest. 2007;117(3): 636-647.
54. Wang SH, Dong L, Luo JY, et al. Decreased expression of serotonin in the jejunum and increased numbers of mast cells in the terminal ileum in patients with irritable bowel syndrome. World J Gastroenterol. 2007;13(45):6041-6047.

55. Dunlop SP, Coleman NS, Blackshaw E, et al. Abnormalities of 5-hydroxytryptamine metabolism in irritable bowel syndrome. Clin Gastroenterol Hepatol. 2005;3(4):349-357.

56. Feldman SA, Eiden LE. The chromogranins: their roles in secretion from neuroendocrine cells and as markers for neuroendocrine neoplasia. Endocr Pathol. 2003;14(1):3-23.

57. Ohman L, Stridsberg M, Isaksson S, Jerlstad P, Simren M. Altered levels of fecal chromogranins and secretogranins in IBS: relevance for pathophysiology and symptoms? Am J Gastroenterol. 2012;107(3): 440-447.

58. Bashashati M, Rezaei N, Andrews CN, et al. Cytokines and irritable bowel syndrome: where do we stand? Cytokine. 2012;57(2): 201-209.

59. Kraneveld AD, Rijnierse A, Nijkamp FP, Garssen J. Neuro-immune interactions in inflammatory bowel disease and irritable bowel syndrome: future therapeutic targets. Eur J Pharmacol. 2008;585(2-3): 361-374.

60. Ohman L, Simren M. Pathogenesis of IBS: role of inflammation, immunity and neuroimmune interactions. Nat Rev Gastroenterol Hepatol. 2010; $7(3): 163-173$

61. Matricon J, Meleine M, Gelot A, et al. Review article: associations between immune activation, intestinal permeability and the irritable bowel syndrome. Aliment Pharmacol Ther. 2012;36(11-12):1009-1031.

62. Scully P, McKernan DP, Keohane J, et al. Plasma cytokine profiles in females with irritable bowel syndrome and extra-intestinal co-morbidity. Am J Gastroenterol. 2010;105(10):2235-2243.

63. Dinan TG, Quigley EM, Ahmed SM, et al. Hypothalamic-pituitary-gut axis dysregulation in irritable bowel syndrome: plasma cytokines as a potential biomarker? Gastroenterology. 2006;130(2):304-311.

64. McKernan DP, Gaszner G, Quigley EM, Cryan JF, Dinan TG. Altered peripheral toll-like receptor responses in the irritable bowel syndrome. Aliment Pharmacol Ther. 2011;33(9):1045-1052.

65. Hughes PA, Harrington AM, Castro J, et al. Sensory neuro-immune interactions differ between Irritable Bowel Syndrome subtypes. Gut. Epub July 27, 2012.

66. Liebregts T, Adam B, Bredack C, et al. Immune activation in patients with irritable bowel syndrome. Gastroenterology. 2007;132(3): 913-920.

67. Chen J, Zhang Y, Deng Z. Imbalanced shift of cytokine expression between $\mathrm{T}$ helper 1 and $\mathrm{T}$ helper 2 (Th1/Th2) in intestinal mucosa of patients with post-infectious irritable bowel syndrome. $B M C$ Gastroenterol. 2012;12:91.

68. Macsharry J, O'Mahony L, Fanning A, et al. Mucosal cytokine imbalance in irritable bowel syndrome. Scand J Gastroenterol. 2008;43(12): 1467-1476.

69. Bashashati M, Rezaei N, Bashashati H, et al. Cytokine gene polymorphisms are associated with irritable bowel syndrome: a systematic review and meta-analysis. Neurogastroenterol Motil. 2012;24(12): 1102-e566.

70. Camilleri M, Katzka DA. Irritable bowel syndrome: methods, mechanisms, and pathophysiology. Genetic epidemiology and pharmacogenetics in irritable bowel syndrome. Am J Physiol Gastrointest Liver Physiol. 2012;302(10):G1075-G1084.

71. Zucchelli M, Camilleri M, Andreasson AN, et al. Association of TNFSF15 polymorphism with irritable bowel syndrome. Gut. 2011; 60(12):1671-1677.

72. Camilleri M, Carlson P, McKinzie S, et al. Genetic susceptibility to inflammation and colonic transit in lower functional gastrointestinal disorders: preliminary analysis. Neurogastroenterol Motil. 2011;23(10): 935-e398.

73. Swan C, Duroudier NP, Campbell E, et al. Identifying and testing candidate genetic polymorphisms in the irritable bowel syndrome (IBS): association with TNFSF15 and TNF $\alpha$. Gut. Epub June 8, 2012. 
74. van der Veek PP, van den Berg M, de Kroon YE, Verspaget HW, Masclee AA. Role of tumor necrosis factor-alpha and interleukin-10 gene polymorphisms in irritable bowel syndrome. Am J Gastroenterol. 2005; 100(11):2510-2516.

75. Barkhordari E, Rezaei N, Ansaripour B, et al. Proinflammatory cytokine gene polymorphisms in irritable bowel syndrome. J Clin Immunol. 2010;30(1):74-79.

76. Villani AC, Lemire M, Thabane M, et al. Genetic risk factors for postinfectious irritable bowel syndrome following a waterborne outbreak of gastroenteritis. Gastroenterology. 2010;138(4):1502-1513.

77. Romero-Valdovinos M, Gudino-Ramirez A, Reyes-Gordillo J, et al. Interleukin-8 and -10 gene polymorphisms in irritable bowel syndrome. Mol Biol Rep. 2012;39(9):8837-8843.

78. Gonsalkorale WM, Perrey C, Pravica V, Whorwell PJ, Hutchinson IV. Interleukin 10 genotypes in irritable bowel syndrome: evidence for an inflammatory component? Gut. 2003;52(1):91-93.

79. Brint EK, MacSharry J, Fanning A, Shanahan F, Quigley EM. Differential expression of toll-like receptors in patients with irritable bowel syndrome. Am J Gastroenterol. 2010;106(2):329-336.

80. Belmonte L, Beutheu Youmba S, Bertiaux-Vandaele N, et al. Role of toll like receptors in irritable bowel syndrome: differential mucosal immune activation according to the disease subtype. PLoS One. 2012;7(8): e42777.

81. Ohman L, Lindmark AC, Isaksson S, et al. Increased TLR2 expression on blood monocytes in irritable bowel syndrome patients. Eur $J$ Gastroenterol Hepatol. 2012;24(4):398-405.

82. Schoepfer AM, Schaffer T, Seibold-Schmid B, Muller S, Seibold F. Antibodies to flagellin indicate reactivity to bacterial antigens in IBS patients. Neurogastroenterol Motil. 2008;20(10):1110-1118.
83. Langhorst J, Junge A, Rueffer A, et al. Elevated human beta-defensin-2 levels indicate an activation of the innate immune system in patients with irritable bowel syndrome. Am J Gastroenterol. 2009;104(2): 404-410.

84. Wehkamp J, Harder J, Weichenthal M, et al. Inducible and constitutive beta-defensins are differentially expressed in Crohn's disease and ulcerative colitis. Inflamm Bowel Dis. 2003;9(4):215-223.

85. Fahlgren A, Hammarstrom S, Danielsson A, Hammarstrom ML. Increased expression of antimicrobial peptides and lysozyme in colonic epithelial cells of patients with ulcerative colitis. Clin Exp Immunol. 2003;131(1):90-101.

86. Camilleri M, Mangel AW, Fehnel SE, Drossman DA, Mayer EA, Talley NJ. Primary endpoints for irritable bowel syndrome trials: a review of performance of endpoints. Clin Gastroenterol Hepatol. 2007;5(5):534-540.

87. O’Mahony L, McCarthy J, Kelly P, et al. Lactobacillus and bifidobacterium in irritable bowel syndrome: symptom responses and relationship to cytokine profiles. Gastroenterology. 2005;128(3):541-551.

88. Corinaldesi R, Stanghellini V, Cremon C, et al. Effect of mesalazine on mucosal immune biomarkers in irritable bowel syndrome: a randomized controlled proof-of-concept study. Aliment Pharmacol Ther. 2009;30(3):245-252.

89. Kokkotou E, Conboy LA, Ziogas DC, et al. Serum correlates of the placebo effect in irritable bowel syndrome. Neurogastroenterol Motil. 2010;22(3):285-e81.
Current Biomarker Findings

\section{Publish your work in this journal}

Current Biomarker Findings is an international, peer-reviewed, open access journal publishing original research, reports, reviews and commentaries on all areas of biomarker research. The manuscript management system is completely online and includes a very quick and fair

\section{Dovepress}

peer-review system. Visit http://www.dovepress.com/testimonials.php to read real quotes from published authors. 